\title{
УДК 331.104.2
}

\section{СТВОРЕННЯ СИСТЕМИ УПРАВЛІННЯ КАДРОВОЮ БЕЗПЕКОЮ НА ПІДПРИЕМСТВІ}

\author{
Mizyc I.I. \\ доктор економічних наук., професор, професор кафедри управління фінансово-економічною безпекою, \\ Університет економіки та права «КРОК», м. Київ, вул. Табірна, 30-32, 03113, Україна \\ тел.: (044)-455-57-07, e-mail.:irynamp@krok.edu.ua \\ ORCID: 0000-0001-6939-9097, DOI: https://doi.org/10.31732/2663-2209-2018-52-213-221
}

\section{CREATING A SYSTEM OF STAFF SECURITY MANAGEMENT AT THE ENTERPRISE}

\author{
I. Mihus \\ doctor of economics, professor, professor of the management of financial and economic security department, \\ «KROK» University, Kyiv, st. Tabirna, 30-32, 03113, Ukraine \\ tel.: (044)-455-57-07, e-mail.: irynamp@krok.edu.ua
}

ORCID: 0000-0001-6939-9097, DOI: https://doi.org/10.31732/2663-2209-2018-52-213-221

\begin{abstract}
Анотація. Досліджено сучасні підходи до трактування поняття «кадрова безпека». Запропоновано авторське визначення поняття «кадрова безпека». Під «кадровою безпекою» пропонується розуміти такий стан управління персоналом, за якого забезпечується нейтралізація зовнішніх та внутрішніх загроз на економічну безпеку підприємства. Запропоновано розглядати кадрову безпеку як одну із функиіональних складових системи управління персоналом з позииій економічної безпеки. Спроектована система управління персоналом з позичій економічної безпеки підприємства. Запропоновано під поняттям «Система управління кадровою безпекою на підприємстві» розуміти систему взаємозв 'язаних заходів щодо створення умов для нормального функиіонування, розвитку та ефективного управління персоналом підприємства за умови забезпечення стабільного стану його системи економічної безпеки.Основними етапами створення системи управління кадровою безпекою підприємства є: прийнятття рішення про формування системи управління кадровою безпекою на підприємстві; розробка концепції формування системи управління кадровою безпекою на підприємстві; розробка внутрішніх положень щодо забезпечення кадрової безпеки; розробка системи управління загрозами економічній безпеці підприємства в процесі управління персоналом; розробка методології оцінки стану системи управління кадрової безпеки підприємства; отримання результатів оцінки стану системи управління кадрової безпеки підприємства; функиіонування системи управління кадровою безпекою підприємства. Розглянуто стратегії управління персоналом на підприємстві, а саме: стратегія економії затрат на персонал; стратегія узгодження прогнозів потреб персоналу з планами розвитку організаиії; стратегія забезпечення підприємства висококваліфікованим персоналом; стратегія додаткових вкладень не тільки в підготовку i розвиток персоналу, а й у створення умов для рачіонального його використання. Запропоновано для забезпечення економічної безпеки на підприємстві розробляти стратегію управління кадровою безпекою, яка полягає у кадровому плануванні діяльності підприємства, щзо дозволить мінімізувати вилив загроз на економічну безпеку з боку персоналу підприємства. Встановлено мету, завдання, функції та приниипи системи управління кадровою безпекою на підприємстві. Систематизовано основні підсистеми та елементи системи управління кадровою безпекою на підприємстві.
\end{abstract}

Ключові слова: управління персоналом, система, кадрова безпека, економічна безпека, підприємство.

Формули: 0, рис.: 3,, табл.: 0, бібл.: 11

Annotation. The modern approaches to the interpretation of the concept "staff security" are investigated. Author's definition of "staff security" is proposed. Under "staff security" it is proposed to understand the state of personnel management, which provides for the neutralization of external and internal threats to the economic security of the enterprise. It is proposed to consider staff security as one of the functional components of the HRl management system from the standpoint of economic security. A system of HR management has been designed from the standpoint of economic security of the enterprise. The concept "staff security management system at the enterprise" is proposed to understand the system of interrelated measures to create conditions for the normal functioning, development and effective HR management of the company, provided that a stable state of its economic security system is maintained. The main stages of creating a system for staff security management of the company are: decision-making on the formation of a HR management system at the enterprise; development of the concept of forming a HR management system at the enterprise; development of internal regulations on staff security; development of a system of management of threats to the economic 
safety of the enterprise in the process of HR management; development of a methodology for assessing the state of the company's staff security management system; obtaining the results of the assessment of the state of the company's staff security management system; functioning of the HR management system of the enterprise. The strategies of HR management at the enterprise are considered, namely: strategy of saving of expenses on the personnel; strategy of coordinating forecasts of the needs of the personnel with the plans of the organization development; the strategy of providing the company with highly qualified personnel; the strategy of additional investments not only in the training and development of personnel, but also in creating conditions for rational use of it. It is proposed to provide the company with an economic security strategy to develop a staff safety management strategy, which consists in personnel planning of the company's activity, which will minimize the impact of threats to economic security on the part of the company's personnel. The purpose, tasks, functions and principles of personnel management system management at the enterprise have been established. The main subsystems and elements of the personnel security management system at the enterprise are systematized.

Keywords: human resources management system, personnel security, economic security, enterprise.

Formulas: 0, fig.: 3, tabl.: 0, bibl.: 11

Постановка проблеми. Останнім часом значна увага приділяється управлінню персоналом у реаліях вітчизняної економіки, проте i на сьогодні не сформований загальний підхід до розуміння сутності та природи такого суспільного феномену як управління персоналом.

При цьому одні дослідники акцентують свою увагу на організаційній природі управління, а інші - за основу своїх суджень беруть змістовну частину, що відображає функціональну сторону управління. Більшість науковців сьогодні за основу своїх досліджень приймають системний підхід, оскільки це дає можливість сприймати управління персоналом як функціональний комплекс в умовах адаптації до мінливого організаційного середовища. Тому традиційно під управлінням персоналу науковці розуміють множину елементів, що в сукупності взаємозв'язків формують єдину систему.

Акцентуючи увагу на системному підході як основному принципі дослідження сутності управління персоналом, ми вважаємо необхідним підкреслити, що системне управління персоналом пов'язано 3 розвитком усіх аспектів управління, тому також потребує використання інтеграційного підходу в подальших дослідженнях управління персоналом на основі теорії систем. При цьому окреме місце в системі управління персоналом належить забезпеченні кадрової безпеки на підприємстві.
Кадрова безпека - найважливіший фактор безпеки всіх сфер діяльності підприємства, нехтування яким здатне не просто завдати серйозного збитку підприємству, але і зруйнувати його.

Кадрова робота особливо важлива на будівельних підприємствах, де практично кожен працівник стає носієм тих чи інших відомостей, що становлять інтерес для конкуруючих фірм або зловмисників.

Аналіз основних досліджень $i$ публікацій. На сучасному етапі, на жаль, автори не дають тлумачення поняття «управління персоналом 3 позищій економічної безпеки», а лише розглядають кадрову безпеку, як одну із функціональних складових системи економічної безпеки підприємства.

Кириченко О. [1] вважає, що кадрова безпека - це правове та інформаційне забезпечення процесу управління персоналом: вирішення правових питань трудових відносин, підготовка нормативних документів, що їх регулюють, забезпечення необхідною інформацією всіх підрозділів управління персоналом. Отже, автор визначає кадрову безпеку переважно 3 правового боку та 3 погляду соціальнотрудових відносин.

Козаченко Г., Пономарьов В., Ляшенко О. зазначають, що кадрова безпека - це процес запобігання негативним діям на безпеку підприємства за рахунок усунення ризиків та загроз, пов'язаних 3 інтелектуальним потенціалом та трудовими відносинами в цілому [2].

На думку Швець Н. кадрова безпека $є$ беззбитковістю трудових відносин 
підприємства, метою якої $є$ досягнення максимальної стабільності функціонування фірми, а також створення основи i перспективи росту з метою виконання iї основних завдань. Перевагою даного підходу є цілісна орієнтація на збереження стабільності функціонування за умов мінливості зовнішнього та внутрішнього середовища [3].

Кібанов А. пропонує кадрову безпеку розглядати як генеральний напрямок кадрової роботи, сукупність принципів, методів, форм організаційного механізму 3 опрацювання цілей, завдань, спрямованих на збереження, зміцнення й розвиток кадрового потенціалу, на створення відповідального і високопродуктивного згуртованого колективу, здатного вчасно реагувати на постійно мінливі вимоги ринку 3 урахуванням стратегії розвитку організації [4].

Досить грунтовно структуру кадрової безпеки запропонував Томаневич Л., за якої iii елементами він визначає: безпеку життєдіяльності, соціально-мотиваційну безпеку, професійну та психологічну безпеку[5].

За результатами проведеного дослідження, пропонуємо під поняттям «кадрова безпека» розуміти такий стан управління персоналом, за якого забезпечується нейтралізація зовнішніх та внутрішніх загроз на економічну безпеку підприємства.

Формулювання цілей статmі. Метою статті $€$ проектування системи кадрової безпеки як складової системи управління персоналом з позицій економічної безпеки підприємств.

Виклад основного матеріалу дослідження. У нашому дослідженні пропонуємо розглядати кадрову безпеку як одну із функціональних складових системи управління персоналом 3 позицій економічної безпеки.

Основні етапи створення системи кадрової безпеки як складової системи управління персоналом 3 позицій економічної безпеки підприємств наведені на рис. 1.
На початковому етапі відбувається прийняття рішення про формування системи управління кадровою безпекою на підприємстві та здійснюється розробка концепції формування даної системи [6], яка включає наступні складові:

- формулювання поняття «системи управління кадровою безпекою на підприємстві»;

- встановлення мети та завдань системи управління кадровою безпекою на підприємстві;

- визначення функцій, які буде виконувати система управління кадровою безпекою на підприємстві;

- визначення принципів, на яких буде грунтуватись система управління кадровою безпекою на підприємстві;

- розробка стратегій формування системи управління кадровою безпекою на підприємстві.

Дослідження праць зарубіжних та вітчизняних науковців дало можливість авторам запропонувати власне визначення поняття «система управління кадровою безпекою на підприємстві».

Система управління кадровою безпекою на підприємстві - це система взаємозв язаних заходів щодо створення умов для нормального функціонування, розвитку та ефективного управління персоналом підприємства за умови забезпечення стабільного стану його системи економічної безпеки.

Основна мета системи управління кадровою безпекою на підприємстві полягає у формуванні та використанні висококваліфікованого та відповідального персоналу, що дозволить мінімізувати вплив загроз на економічну безпеку підприємства.

Виходячи з цього, основним завданням системи управління кадровою безпекою на підприємстві: використання i розвитку персоналу; вибір і реалізація стилю управління персоналом; організації горизонтальної координації і кооперації; покрашення організації робочих місць i умов прані; визнання особистих досягнень у праці; вибір системи оплати й стимулювання [7]. 
ISSN (Print) 2307-6968, ISSN (Online) 2663-2209

Вчені записки Університету «КРОК» №4 (52), 2018

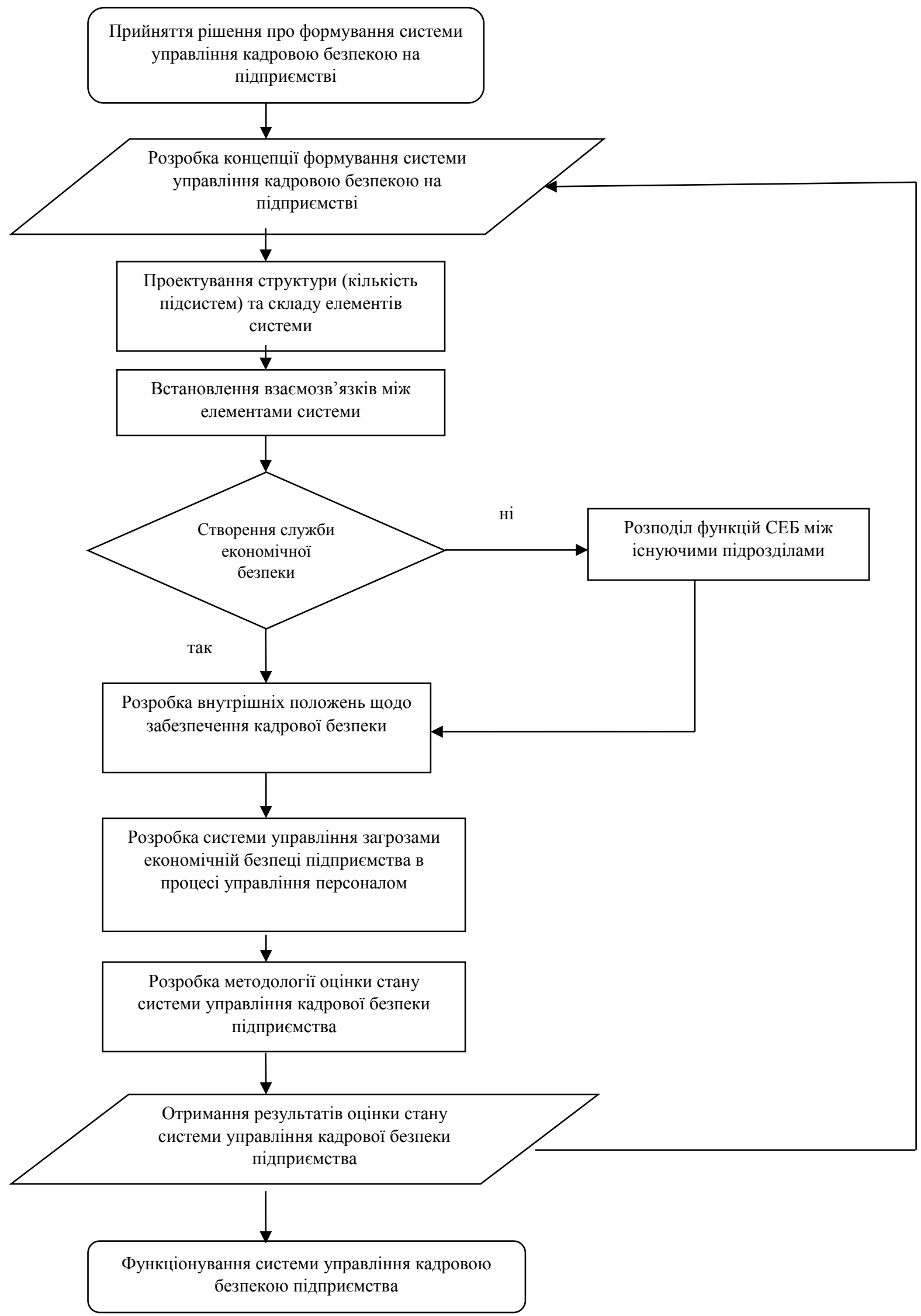

Рис. 1. Модель формування системи управління кадровою безпекою підприсмства Складено особисто автором 
Система управління кадровою безпекою на підприємстві як иілісна система виконує такі функиї:

- організаційну — планування потреб і джерел комплектування персоналу;

- соціально-економічну забезпечення комплексу умов і факторів, спрямованих на раціональне закріплення й використання персоналу;

- відтворювальну - забезпечення розвитку персоналу.

На нашу думку, на сучасному етапі розвитку економіки України принципи управління персоналом повинні грунтуватись на законах розвитку суспільства, повністю відображати зв'язки і відносини між керівниками та підлеглими, мати правове оформлення.

Вважаємо, що до основних принципів управління кадровою безпекою слід віднести:

1. Готовність до взаємного компромісу між керівництвом та працівниками.

2. Формування взаємної довіри керівників і трудового колективу.

3. Орієнтація на досягнення лояльності персоналу до компанії.

4. Втримання ключових працівників підприємства.

5. Зменшення загального рівня стресу та конфліктів у трудовому колективі.

6. Прозорість та відкритість діяльності підприємства для працівників.

7. Інноваційність в управлінні персоналом.

8. Зменшення загроз економічній безпеці підприємства в результаті управління персоналом.

Вибір стратегії управління персоналом визначається реальними умовами роботи підприємства, 3 врахуванням яких можна вибирати такі стратегії [8-11]:

1) стратегія економії затрат на персонал;

2) стратегія узгодження прогнозів потреб персоналу з планами розвитку організації;

3) стратегія забезпечення підприємства висококваліфікованим персоналом;
4) стратегія додаткових

вкладень не тільки в підготовку i розвиток персоналу, а й у створення умов для раціонального його використання.

Зазначені стратегії не дозволяють здійснювати безпосереднє забезпечення економічної безпеки підприємства, тому автори пропонують розробляти стратегію управління кадровою безпекою, яка полягає у кадровому плануванні діяльності підприємства, що дозволить мінімізувати вплив загроз на економічну безпеку з боку персоналу підприємства.

Запропоновану автором систему управління кадровою безпекою підприємства пропонуємо розглядати як систему, що складається з таких підсистем (рис. 2.).

Розглядаючи систему управління кадровою безпекою підприємства, до основних ї̈ елементів пропонуємо віднести такі: об'єкти, субєкти, ноормативноправове забезпечення, функціональні складові, механізм реалізації системи управління кадровою безпекою на підприємстві (рис. 3).

Об'єктом системи виступає персонал підприємства. Суб'єктами системи є особи, підрозділи, служби, органи, відомства, установи, які безпосередньо впливають на забезпечення економічної безпеки підприємства при здійсненні управління персоналом, а саме: керівництво; служба управління персоналом; служба економічної безпеки ; органи державного регулювання; профспілкові організації; кадрові та рекрутингові агенції.

Нормативно-правове регулювання процесу управління кадровою безпекою підприємства грунтується на:

- Конституції України;

- міжнародних правових актах, ратифікованих Верховною радою України;

- Господарському та Податковому кодексах, Кодексі Законів про працю;

- законах України («Про зайнятість населення» тощо);

- підзаконних актах органів державного регулювання; 
- внутрішніх документах підприємства (Статут, Положення про Службу економічної безпеки, Положення про комерційну таємницю, Положення про мотивацію персоналу, Колективний догорів тощо).

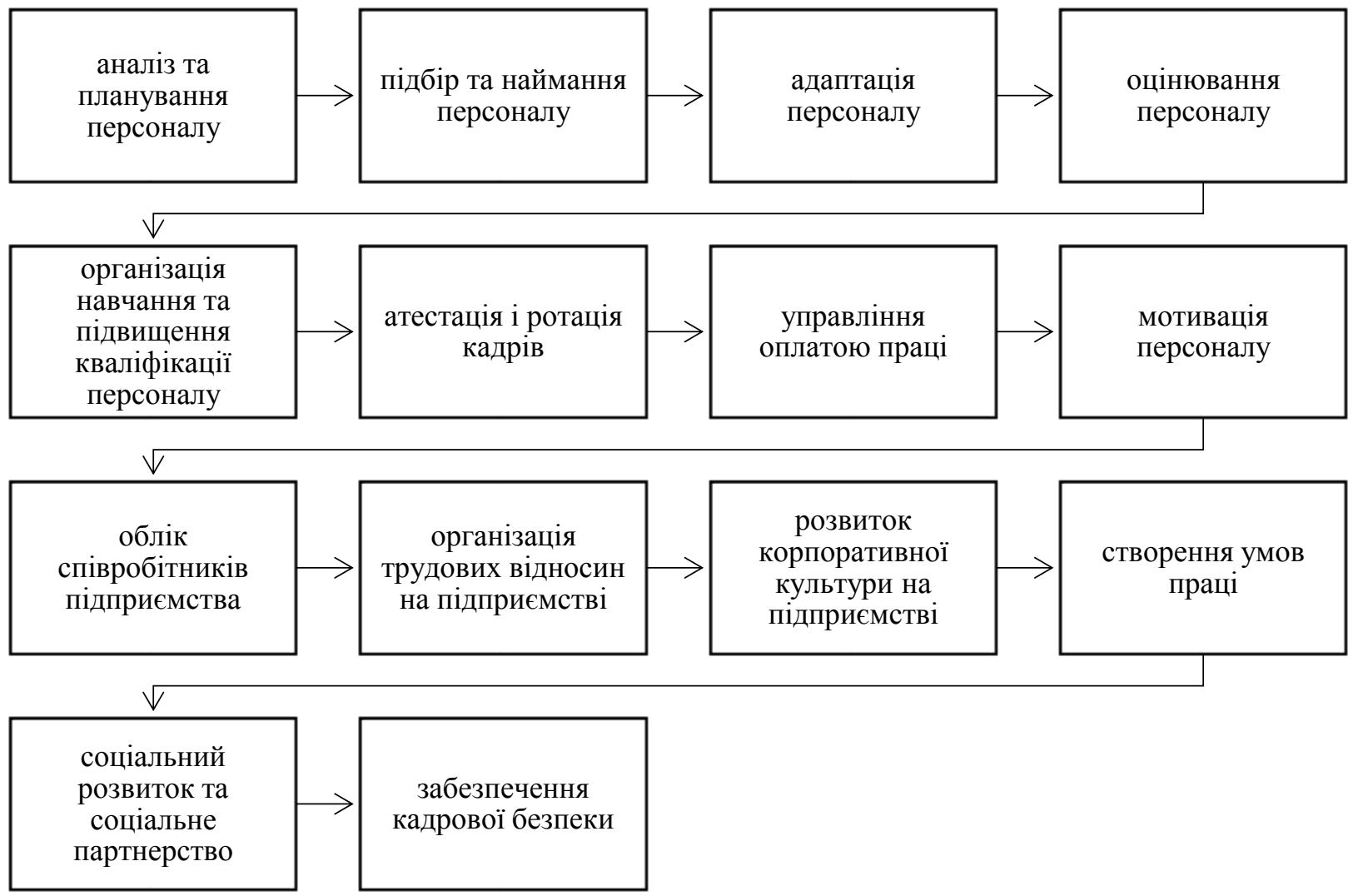

\section{Рис. 2. Основні підсистеми системи управління кадровою безпекою підприсмства та взасмозв'язок між ними}

Складено особисто автором

Основні функиіональні складові системи управління кадровою безпекою підприємства є представлено на рис. 3 [6]. Ïх вибір грунтується на особливостях функціонування системи управління кадровою безпекою на підприємстві та залежать від розміру підприємства, видів його діяльності, організаційно-правової форми тощо.

3 метою оцінки стану системи управління кадровою безпекою на підприємстві виникає необхідність розробки методологічного забезпечення, яке дозволить послідовно та комплексно провести відповідний аналіз та запропонувати відповідні заходи щодо відновлення стабільного стану зазначеної системи.
В якості методологічного забезпечення автором була запропонована методологія комплексної оцінки стану системи управління кадровою безпекою на підприємстві, яка дозволяє здійснити комплексну оцінку стану відповідної системи на основі економіко-математичної моделі, до складу якої входять результати, отримані від чотирьох методик оцінки, а саме:

- показники, що характеризують витрати на персонал;

- показники, що характеризують якість процесів з управління персоналом;

- показники, що характеризують результативність управління персоналом;

- показники, що характеризують стан кадрової безпеки персоналу підприємства. 
• персонал підприємства

Об єкти системи

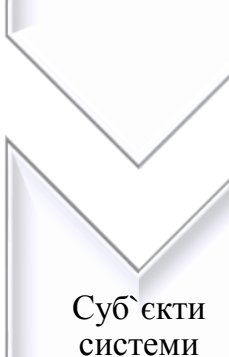

- керівництво;

• служба управління персрналом;

- служба економічної безпеки ;

• органи державного регулювання;

системи

• профспілкові організації;

•кадрові та рекрутингові агенції

•Закони України;

- Інші нормативно-правові акти;

Нормативноправове

• внутрішні положення та інструкції

регулювання

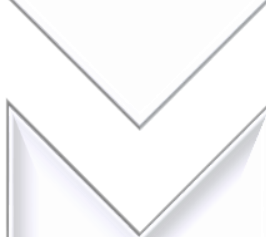

Функціональні складові системи

\section{- фінансова;}

- корпоративна;

• правова;

- майнова;

•кадрова;

- технологічна;

• інформаційна (інформаційно-аналітична; інформаційно-психологічна);

• екологічна

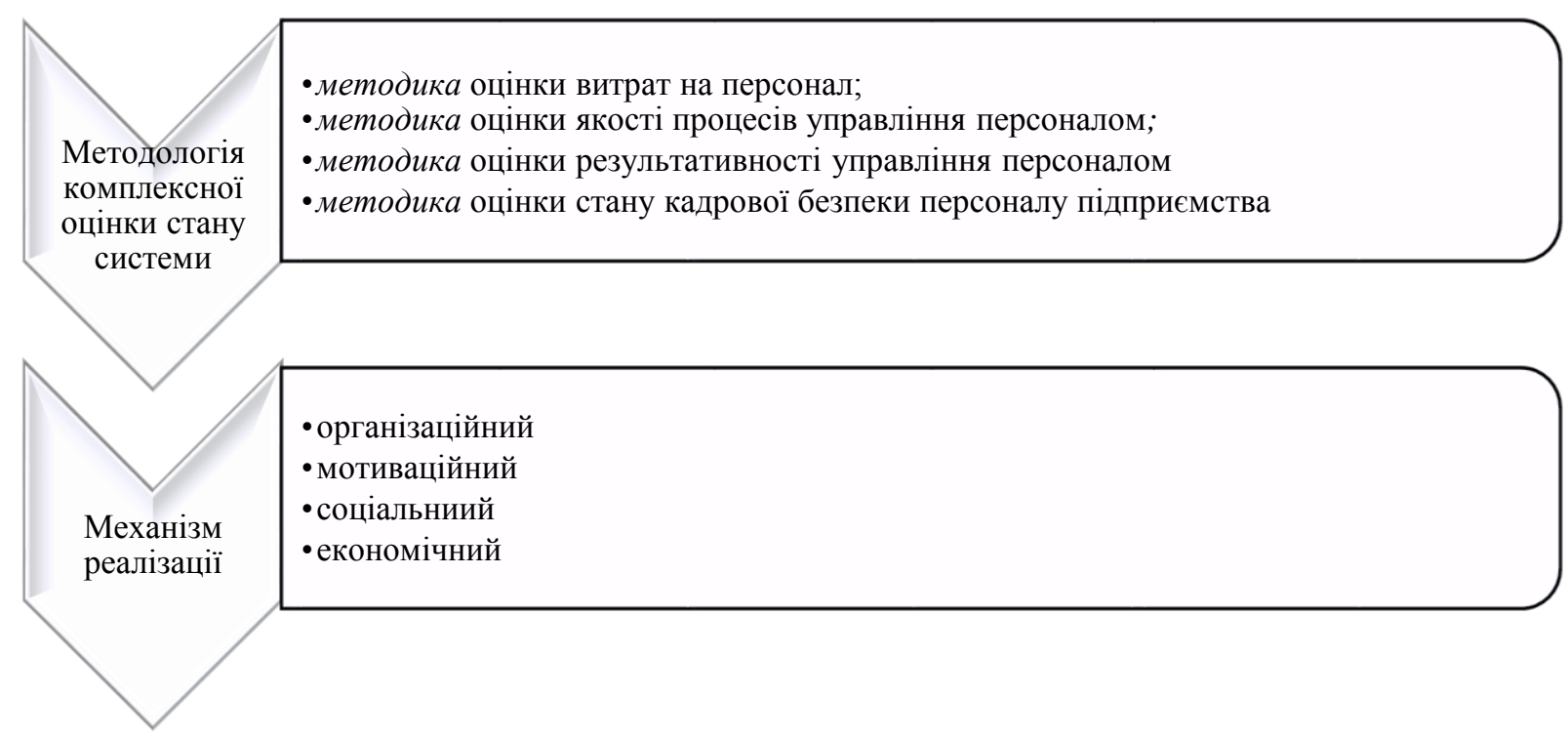

Рис. 3. Основні елементи системи управління кадровою безпекою підприсмства Складено особисто автором 
До складу механізму реалізащії системи управління кадровою безпекою підприємства пропонуємо включити:

1) організаційний механізм, що передбачає прогнозування структури, визначення потреб, залучення, підбір та розміщення персоналу й укладання договорів та контрактів;

2) мотиваційний механізм, що передбачає формування банку даних 3 питань рівня кваліфікації, персональних умінь, бажань, результатів оцінки праці $з$ метою визначення потенціалу кожного працівника для організації навчання, підвищення кваліфікації і закріплення чи звільнення працівників.

3) соиіальний механізм, що включає професійно-кваліфікаційне і посадове переміщення працівників (управління кар'єрою), створення постійного складу персоналу та робочих місць, покращення морально-психологічного клімату в колективі.

4) економічний механізм, що передбачає управління витратами на персонал; стимулювання персоналу; управління витратами на створення та/або забезпечення діяльності служби економічної безпеки.

Коригування основних складових запропонованої системи управління кадровою безпекою на підприємстві може здійснюватися під впливом зовнішніх та внутрішніх загроз економічній безпеці підприємства 3 урахуванням етапів, наведених на рис. 1.

Вважаємо, що саме така послідовність сприятиме гнучкості запропонованої системи та ефективному управлінню кадровою безпекою як складової системи управління персоналом 3 позицій економічної безпеки підприємств.

Запропонована авторами система управління кадровою безпекою як складова системи управління персоналом дозволить дозволить мінімізувати вплив загроз на економічну безпеку 3 боку персоналу підприємства.

Висновки. Результати проведеного дослідження дозволили зробити наступні висновки.
1. Досліджено сучасні підходи до трактування поняття «кадрова безпека». Запропоновано авторські визначення понять «кадрова безпека» та «система управління кадровою безпекою на підприємстві». Запропоновано розглядати кадрову безпеку як одну із функціональних складових системи управління персоналом підприємства.

2. Спроектована система управління персоналом $з$ позицій економічної безпеки підприємства. Окреслено основні етапи створення системи управління кадровою безпекою підприємства.

3. Встановлено мету, завдання, функції та принципи системи управління кадровою безпекою на підприємстві. Систематизовано основні підсистеми та елементи системи управління кадровою безпекою на підприємстві.

\section{Jimepamypa:}

1. Кириченко О. А., Денисенко М. П., Сідак В. С., Лаптев C. M. та ін. Проблеми управління економічною безпекою суб'єктів господарювання : монографія. Київ, 2010. 412 с.

2. Ляшенко О. М., Погорелов Ю. С. та ін. Система економічної безпеки: держава, регіон, підприємство: монографія : в 3 т. Т.1 / за заг. ред. Г.В. Козаченко. Луганськ, 2010. 282 с.

3. Швець Н. Методи виявлення і збереження кадрової безпеки, або як перемогти зловживання персоналу. Персонал : журнал. 2006. № 5.

4. Кибанов А. Я. Управление персоналом организации : пособие. Москва : ИНФРА-М, 2002. $638 \mathrm{c}$.

5. Томаневич Л. М. Кадрова безпека підприємства як об'єкт теоретичного дослідження. Збірник наукових праць Львівського державного університету внутрішніх справ. Серія: Економічні науки : зб. наук. праць. Львів, 2009. № 1. С. 1-8.

6. Мігус (Шульга) I. П. Система економічної безпеки емісійної діяльності акціонерних товариств. Економічний часопис - XXI : журнал. 2010. №11-12. C. 64-68.

7. Кадрова безпека суб'єктів господарської діяльності: менеджмент інсайдерами: монографія / за ред. проф. Сідака В.С., проф. Мігус І.П. Черкаси, 2012. $258 \mathrm{c}$.

8. Меньшикова М. О. К вопросу об управлении персоналом как системе и интегррованной подсистеме оргаизации. URL : http://scientificnotes.ru/pdf.

9. Крушельницька О. В. Управління персоналом навчальний посібник. Київ : Кондор, 2003. 296 с.

10. Полонская Л. А. Управление персоналом конспект лекций. Донецк: ДИТБ, 2001. 173 с. 
11. Система управления персоналом: основные элементы и принципы формирования. URL : http://arkadacentre.ru/sistemUP.htm.

\section{Reference:}

1. Kyrychenko O. A., Denysenko M. P., Sidak V. S., Laptiev S. M. ta in. Problemy upravlinnia ekonomichnoiu bezpekoiu subiektiv hospodariuvannia : monohrafiia. Kyiv, 2010. 412 s.

2. Liashenko O. M., Pohorelov Yu. S. ta in. Systema ekonomichnoi bezpeky: derzhava, rehion, pidpryiemstvo: monohrafiia : v 3 t. T.1 / za zah. red. H.V. Kozachenko. Luhansk, 2010. 282 s.

3. Shvets N. Metody vyiavlennia i zberezhennia kadrovoi bezpeky, abo yak peremohty zlovzhyvannia personalu. Personal : zhurnal. 2006. № 5.

4. Kybanov A. Ya. Upravlenye personalom orhanyzatsyy : posobye. Moskva : YNFRA-M, 2002. $638 \mathrm{~s}$.

5. Tomanevych L. M. Kadrova bezpeka pidpryiemstva yak obiekt teoretychnoho doslidzhennia. Zbirnyk naukovykh prats Lvivskoho derzhavnoho universytetu vnutrishnikh sprav. Seriia: Ekonomichni nauky : zb. nauk. prats. Lviv, 2009. № 1. S. 1-8.
6. Mihus (Shulha) I. P. Systema ekonomichnoi bezpeky emisiinoi diialnosti aktsionernykh tovarystv. Ekonomichnyi chasopys - KhKhI : zhurnal. 2010. №1112. S. 64-68.

7. Kadrova bezpeka subiektiv hospodarskoi diialnosti: menedzhment insaideramy: monohrafiia / za red. prof. Sidaka V.S., prof. Mihus I.P. Cherkasy, 2012. $258 \mathrm{~s}$.

8. Menshykova M. O. K voprosu ob upravlenyy personalom kak systeme y yntehrrovannoi podsysteme orhayzatsyy. URL : http://scientific-notes.ru/pdf.

9. Krushelnytska O. V. Upravlinnia personalom navchalnyi posibnyk. Kyiv : Kondor, 2003. 296 s.

10. Polonskaia L. A. Upravlenye personalom konspekt lektsyi. Donetsk: DYTB, 2001. 173 s.

11. Systema upravlenyia personalom: osnovnыe эlementы y pryntsypы formyrovanyia. URL : http://arkadacentre.ru/sistemUP.htm.

Стаття надійшла до редакиії 25.11.2018р. 